\title{
Isolation, Screening and Time Course Study of Amylase- producing Fungi from Garri Processing Environment
}

\author{
Francis Sopuruchukwu Ire ${ }^{1, *}$, Sotonye Ipalibo-Wokoma ${ }^{1}$, Augustine Onwuchekwa Okoli ${ }^{2}$ \\ ${ }^{1}$ Department of Microbiology, Faculty of Science, University of Port Harcourt, Nigeria (francis.ire@uniport.edu.ng; \\ sotie234@gmail.com) \\ ${ }^{2}$ Department of Science Laboratory Technology, Federal Polytechnics, Oko, Anambra State, Nigeria (okoli4john@gmail.com) \\ *Correspondence: francis.ire@uniport.edu.ng
}

\begin{abstract}
Amylases (E.C.3.2.1.1) are enzymes which catalyze the breakdown of $\alpha-1,4$ glycosidic linkages of starch to simple sugars and different monomeric products. Microbial amylases are essential enzymes compared with animals and plants amylases in industrial applications. Thus, in southern Nigeria, garri processing waste-water from mills poses a serious environmental challenge and this situation could be exploited by utilizing microorganisms colonizing the area to manufacture microbial products. This present study was aimed at evaluating the potential of fungi isolated from garri processing environment for amylase secretion and conduct a time course study of the enzyme production. Fungi were isolated from the soil and waste water from garri processing sites using Standard Microbiological Procedures. The five fungi isolated from garri processing environmental samples were screened using Lugol's iodine. Three fungal isolates were then selected on the hydrolysis of starch in qualitative zonation agar plates but one isolate named B among them was better in starch hydrolysis related to highest clear zone plates. After qualitative screening, the three hyper production amylase extracted fungi were identified according to the morphological characteristics. The hyper producing amylase isolate B was then identified as Aspergillus flavus (RCBBR_AEAFUN2) and recorded as a novel strain in southern Nigeria according to molecular characteristics, which was selected for further studies. The current results of time course study showed that the maximum growth $(2.453 \mathrm{~g})$ occurred after $24 \mathrm{~h}$ of incubation at pH 4.5 while maximum enzyme production $(2.3 \mathrm{U} / \mathrm{ml} / \mathrm{min})$ was obtained after $96 \mathrm{~h}$ of incubation at pH 3.5. Therefore, the hyper producing amylase from garri processing sites, Aspergillus flavus (RCBBR_AEAFUN2) novel strain has great prospects for future biotechnological and industrial applications and help in ameliorating the environmental pollution posed by the waste-water.
\end{abstract}

Keywords: Amylase, Fungi, Garri Processing, Screening, Time Course

Received: October $10^{\text {th }}, 2020 /$ Accepted: December $14^{\text {th }}, 2020 /$ Online: December $20^{\text {th }}, 2020$

\section{INTRODUCTION}

Amylases (E.C.3.2.1.1) are used in many bioindustrial processes and account for a reasonable fraction of the world industrial enzyme markets (Singh et al., 2016). Amylases catalyse hydrolysis of starch to simple sugars used as raw materials for various products thereby making the enzymes essential in the food and energy sector (Okolo et al., 2000, Fang et al., 2019). Generally, amylases are grouped into $\alpha, \gamma, \beta$ subtypes. Bacteria, fungi, and yeast are sources of microbial amylases which are mainly for scientific research and industrial sector (Gopinath et al., 2017). Food fermentation, pharmaceutical, bakery, paper, brewing, detergent and textiles are industrial applications of amylases (Saini et al., 2017; Asrat and Girma, 2018). Sourcing amylases from microorganisms especially fungi are advantageous because the organism could easily be manipulated and bulk production of the enzyme is economical (Sunitha et al., 2012; Ogbonna et al., 2014).

Nigeria has been adjudged to be among the largest producer of cassava in the world which accounts for 30 out of 84 million tonnes of cassava produced annually in Africa (Obueh and Odesiri-Eruteya, 2016; Omilani et al., 2019). Cassava processing in the country is mainly handled by small-scale farmers around their neighbourhood which poses environmental pollution due to inappropriate disposal of waste which percolate into the soil (Kolawole, 2014; Obueh and Odesiri-Eruteyan, 2016). Cassava milling is among the major industries in southern Nigeria (Obueh and Odesiri-Eruteyan, 2016). It is estimated that $70 \%$ of cassava tubers harvested in Nigeria, approximately 10 million tonnes are processed into garri, annually. The soil around garri processing sites are usually contaminated by spill or underground leakage of cassava waste water 
which are usually not treated by the local producers (Oboh, 2005; Kolawole, 2014). Nevertheless, exploiting microorganisms found in a garri processing site which is usually polluted for the production of microbial products is a research-driven effort with economic benefits (Elijah and Asamudo, 2016; Pham et al., 2019).

Using traditional microbiological methods, Ogbonna et al. (2014) identified fungal isolates namely Aspergillus niger, Penicillium sp. and Chrysosporium sp. from garri processing site with varying potentials to produce amylase. In a recent study, Elijah and Asamudo (2016) identified twenty-seven fungal species from cassava waste water using molecular methods and reported Saccharomyces cerevisiae $(8.7 \%)$ and Candida krusei $(8.7 \%)$ as the dominant species. According to Ayansina et al. (2014), microorganisms capable of producing amylase could be found in soils around mills, cassava farms etc. Although, their research findings have industrial applications, involving molecular methods to identify the specific strains of fungi genera isolated from different environments which possess potentials to produce ample quantity of microbial amylase could offer huge economic benefits (Ottoni et al., 2020). Therefore, this study is aimed at isolating, screening and identification of fungal strains using molecular methods from garri processing sites with the hyper producing amylases.

\section{MATERIALS AND METHODS}

\section{A. Sample collection}

Soil and waste-water samples were collected from a garri processing site at Alakahia junction, Obio/Akpor Local Government Area, using a sterile polyethene bag and shovel. The soil sample was transferred immediately to Microbiology Laboratory, the University of Port Harcourt, Rivers State for analysis.

\section{B. Isolation of fungi}

The method described by Ogbonna et al. (2014) was adopted. The soil sample was cultured on Potato dextrose agar (PDA) plates by spread plate method. Ten grams $(10 \mathrm{~g})$ of the soil sample or $10 \mathrm{ml}$ of waste-water was transferred into $90 \mathrm{ml}$ of sterile normal saline. Ten-fold serial dilution was done using a sterile pipette for each transfer to obtain different dilution factors. Exactly $0.1 \mathrm{ml}$ from $10^{-4}$ and $10^{-5 a}$ dilutions was pipetted and spread on Potato dextrose agar (PDA) prepared in Petri dishes with the aid of a sterile hockey stick. The PDA plates were incubated at $28{ }^{\circ} \mathrm{C}$ for $72 \mathrm{~h}$.

\section{Purification and identification of fungal isolates}

The culture plates were observed for cultural macroscopic characteristics of the isolates which includes colony diameter, colour, texture, conidial colour, mycelia colour and nature of the spores. Based on morphological features, different fungal isolates were subcultured repeatedly on fresh PDA plates, incubated at $28{ }^{\circ} \mathrm{C}$ for $48 \mathrm{~h}$ until a pure culture was obtained. Microscopical observation of fungal species was carried out following lactophenol cotton blue staining of the isolates using the procedure described by Cappuccino et al. (2004). An aliquot portion of the fungal mat was aseptically placed on the slide. Three drops of lactophenol cotton blue was applied on the fungal isolate on the slide, allowed to stay for 2- $3 \mathrm{~min}$. Excess stain was blotted out, coverslip was placed over the stain on the slide and the slide was viewed under microscope using $10 \mathrm{X}$ and $40 \mathrm{X}$ magnification.

\section{Qualitative screening of fungal isolates for amylase producers}

All the pure isolates obtained were screened for actual and efficient starch degraders. The method described by (Batista $e t$ al. (2018) was adopted with slight modification using starch hydrolysis approach on PDA. The pure fungal cultures were inoculated on a freshly prepared starch agar medium and plates were incubated for $48 \mathrm{~h}$ at room temperature $\left(37^{\circ} \mathrm{C}\right)$. After $48 \mathrm{~h}$ of incubation, the plates were flooded with the Lugol's iodine to determine any starch hydrolysis. Clearing zones around the colonies were measured and used to evaluate the level of amylase activity (Batista et al., 2018). This is as indication of starch hydrolysis by the fungi isolates which reflects amylase secretion. The size of the zone of clearance corresponds to amylase production (Kumar, 2016). The fungal isolate with the highest zone of clearance was regarded as the isolate with better amylolytic properties and hence selected for further studies Ominyi et al. (2013).

\section{E. Inoculum preparation}

Inoculum preparation was performed as previously reported (Ire et al., 2017). Fungal cells from $48 \mathrm{~h}$ old slant culture was used for the inoculation. Spore suspension of the fungus was prepared by pouring ten milliliters $(10 \mathrm{ml})$ of sterile distilled water containing two drops of $0.1 \%$ Tween 80 to the surface of the slant with luxuriant spore growth. A sterile inoculation needle was used to scrape the spore clumps under aseptic conditions after which the tube was vigorously shaken to homogenize the suspension. This suspension was used for inoculation of fermentation medium.

\section{F. Quantitative screening of fungal isolates for amylase production in submerged fermentation}

Secondary screening process was performed to quantitatively evaluate the fungal isolates for the production of amylase under submerged fermentation using a basal medium which consisted of (in gram per litre) soluble starch, 20; $\mathrm{KH}_{2} \mathrm{PO}_{4}, 14 ; \mathrm{NH}_{4} \mathrm{NO}_{3}$, $10 ; \mathrm{KCl}, 0.5 ; \mathrm{MgSO} 4.7 \mathrm{H}_{2} \mathrm{O}, 0.1 ; \mathrm{FeSO} 4.7 \mathrm{H}_{2} \mathrm{O}, 0.01$. The initial $\mathrm{pH}$ of the medium was adjusted 6.9 with concentrated $\mathrm{HCl}$. One hundred millilitre $(100 \mathrm{ml})$ of the medium was distributed into $250 \mathrm{ml}$ Erlenmeyer flasks and autoclaved at $121{ }^{\circ} \mathrm{C}, 15 \mathrm{psi}$ for $15 \mathrm{~min}$. The sterilized medium was thereafter was cooled to room temperature $\left(24-37{ }^{\circ} \mathrm{C}\right)$. The pure fungal isolate was separately inoculated into the sterilized basal medium. The plates were incubated at $37{ }^{\circ} \mathrm{C}$ for 5 days in a shaker. At the end of the fermentation, the broths were centrifuged at $7000 \mathrm{rpm}$ for 
30 min at $4{ }^{\circ} \mathrm{C}$ to obtain the crude enzyme. The culture filtrates which represents the crude enzyme was used to hydrolyze fresh starch solution and assayed for $\alpha$-amylase activity. All experiments were conducted in triplicates.

\section{G. Enzyme assay}

Amylase assay was performed according to the method of Miller (1959) with slight modification. The reaction mixture consisted of $1 \mathrm{ml}$ of $1 \%$ soluble starch solution and $1 \mathrm{ml}$ of potassium phosphate buffer, $\mathrm{pH} 6.9$ and $0.1 \mathrm{ml}$ of the crude enzyme, all were contained in a test tube and incubated for 15 min at room temperature $\left(37^{\circ} \mathrm{C}\right)$. Thereafter, two millilitre $(2$ $\mathrm{ml}$ ) of the DNS was added to the reaction mixture to terminate the enzyme action. The mixture in the test tube was boiled for at $100{ }^{\circ} \mathrm{C}$ for $10 \mathrm{~min}$ for colour development. The absorbance of the supernatant after centrifugation was determined at 540 $\mathrm{nm}$ using spectrophotometer (UNICAM) for the estimation of reducing sugar liberated. Maltose was used as a standard for reducing sugar released. One unit (U) of amylase activity was described as the amount of enzyme that released $\mu$ mol of reducing sugar per minute under the assay conditions. The activity of the enzyme was calculated by using following formula (Dash et al., 2015).

Amylase activity $(\mathrm{U} / \mathrm{ml} / \mathrm{min})=$

Maltose released $(\mu \mathrm{g}) \times T V$ of reactive media $(m L) \times D F$ MW of maltose $\times$ Enzyme used $(\mathrm{mL}) \times$ Time of incubation $(\mathrm{min})$

$\mathrm{TV}=$ Total volume

$\mathrm{DF}=$ Dilution factor

$\mathrm{MW}=$ Molecular weight

\section{H. Time course study for the production of amylase and growth of Aspergillus flavus}

The time course study for the production and growth of the fungus was investigated in submerged fermentation using a basal medium containing $(\mathrm{g} / \mathrm{L})$ starch 20 , yeast extract 0.5 , $\mathrm{KH}_{2} \mathrm{PO}_{4} 10,\left(\mathrm{NH}_{4}\right)_{2} \mathrm{SO}_{4} 10.5, \mathrm{MgSO}_{4} .7 \mathrm{H}_{2} \mathrm{O} \quad 0.5, \mathrm{CaCl}_{2} 0.5$, $\mathrm{FeSO}_{4} .7 \mathrm{H}_{2} \mathrm{O}$ trace element, $\mathrm{MnSO}_{4} .7 \mathrm{H}_{2} \mathrm{O} \quad 0.004$ and $\mathrm{ZnSO}_{4} \cdot \mathrm{H}_{2} \mathrm{O}$ trace element. The medium was adjusted to $\mathrm{pH} 6.9$. One hundred millilitre $(100 \mathrm{ml})$ of the medium was dispensed into $250 \mathrm{ml}$ Erlenmeyer flasks and autoclaved at $121{ }^{\circ} \mathrm{C}, 15 \mathrm{psi}$ for $15 \mathrm{~min}$. Two (2) $\mathrm{mL}$ of $24 \mathrm{~h}$ old fungal culture was inoculated into $250 \mathrm{~mL}$ Erlenmeyer flasks containing 100 $\mathrm{mL}(\mathrm{w} / \mathrm{v})$ of medium at initial $\mathrm{pH} 6.9$ (adjusted with concentrated $\mathrm{HCl}$ ). The fermentation contents were incubated in an orbital shaker incubator $(150 \mathrm{rpm})$ at $37^{\circ} \mathrm{C}$ for $120 \mathrm{~h}(5$ days). Samples were collected and analyzed after every $24 \mathrm{~h}$ for 5 days for amylase activity, protein content, biomass and final $\mathrm{pH}$. At each day, recovery of crude enzyme from fermentation broth was done by centrifugation at 7,000 rpm for $30 \mathrm{~min}$ at $4^{0} \mathrm{C}$. The clear cell free supernatant was collected and used for the estimation of amylase activity and protein content while the filtrate was used for biomass estimation. All experiments were carried out in triplicates.

\section{Determination of cell biomass}

The fungal biomass was expressed as dry weight and was determined as described by Ire and Ike (2014). At the end of each fermentation, the mycelium was filtered through filter paper (Whatman No. 1). The filtrate was washed with distilled water and dried in a hot air oven at $105^{\circ} \mathrm{C}$ to constant mass. Thereafter, it was placed in the desiccator and the weight determined.

\section{J. Estimation of protein}

The method described by Lowry et al. (1951) was used to determine the protein content before and after the fermentation process. Bovine serum albumin was used as the standard.

\section{K. Molecular identification of the fungal isolate}

Molecular identification was performed using 18S rRNA gene technology as described by Ire and Nwanguma (2020). Universal primer was used for the amplification of $18 \mathrm{~S}$ rRNA gene of the isolate. The genomic DNA of isolate was amplified using universal primers for $18 \mathrm{~S}$ rRNA gene of fungus. Thermal cycler was applied for the amplification with a temperature profile standardized for $18 \mathrm{~S}$ rRNA gene amplification.

\section{Fungal genomic DNA extraction}

The extraction of total genomic DNA of a pure fungal culture was performed using Quick-DNA ${ }^{\mathrm{TM}}$ Fungal/Bacterial Miniprep Kit (Zymo Research Group, California, USA). This was achieved by following the protocol developed by the manufacturer with slight modification as described by Saitou and Nei (1987).

\section{Quantification and concentration of DNA material using NanoDrop}

After the extraction of the fungal DNA, the extracted DNA was quantified by employing the Thermo-scientific Nanodrop 2000C spectrophotometer (Thermo Fisher Scientific Inc. Wilmington, Delaware, USA). The procedure described by Saitou and Nei (1987) was adopted to determine the purity and concentration of their Nucleic acid as well as the minimum and maximum levels of its unit.

\section{N. Gel electrophoresis}

Gel electrophoresis was carried out using a modified method of Saghai-Maroof et al. (1984). Five grams (5.0 g) of agarose powder was mixed with $50 \mathrm{ml}$ of TrisBoris EDTA (TBE) $1 \mathrm{X}$ in a measuring flask and microwaved for 2 min to obtain a clear solution. Thereafter, $13 \mu \mathrm{L}$ of ethidium bromide was included to the contents in the conical flask and transferred into the casting tray. The comb was placed within the casting tray and allowed undisturbed for 20 - $30 \mathrm{~min}$ at room temperature (24$37^{\circ} \mathrm{C}$ ) until the gel solidifies. The gel electrophoresis unit was then set up; the gel holder containing the gel was gently dropped 
in the gel tank. TBE $1 \mathrm{X}$ was poured directly into the gel tank until the gel was completely covered. Molecular weight marker (1 Kb DNA Ladder) was loaded into the first lane, and the DNA samples were separately loaded into the wells created by the comb on the gel. Each DNA sample $(3 \mu \mathrm{L})$ was mixed with 3 $\mu \mathrm{L}$ of $2 \mathrm{X}$ loading and loaded in one lane on the gel. A control was also loaded which contained all components of the PCR reaction mixture except template DNA. This set up was allowed to run for $40 \mathrm{~min}$ at 100 volts. At the end of the running time, the DNA fragments were visualized with UV transilluminator (Gel Documentation microDOCTM, Cleaver Scientific Ltd, UK).

\section{O. Sequencing}

Sequencing was performed according to the procedure described by Jukes and Cantor (1969). The forward and reverse sequences were assembled using the BigDye Teminator Kit on a 3510 ABI sequencer by Inquaba Biotechnological, Pretoria South Africa.

\section{P. Phylogenetic analysis}

The resulting sequence was edited with the application of bioinformatics algorithm Trace Edit. The sequence was compared with the information gotten from GenBank database of the National Centre of Biotechnology Information (NCBI) using the basic local alignment search tool (BLASTN) (Pruitt et al., 2005). The nucleotide sequence obtained was aligned using ClustalX and the Neighbour-joining phylogenetic tree was constructed with MEGA 6.0 software (Felsenstein, 1985; Saitou and Nei, 1987; Pruitt et al., 2005; Tamura et al., 2007). The Jukes-Cantor method was applied to compute the evolutionary distances (Jukes and Cantor, 1969). The maximum likelihood method was adopted to contrast the phylogenetic tree and the reliability of inferred trees was assessed from 500 replicates with bootstraps consensus tree procedure.

\section{Q. Statistical analysis}

Variance analysis (ANOVA), Student's t-Test (t-test) and Tukey (at $\mathrm{P}=0.05$ ) were used as a statistical tool to analyse the zone of clearance and starch hydrpolysis performed in spectrophotometer (triplicate) employing the IBM SPPS package version 22 Computer program. The data generated from the triplicate experiments were reported as the means \pm standard errors of the means.

\section{RESULTS}

\section{A. Screening and selection of fungal isolates for the secretion of amylase}

Garri processing waste water dump site and surrounding soil are rich sources of amylase producing microorganisms. Selection of microorganisms is the major key when there is need for production of enzymes with high activity and economic value. Data presented in Table 1 depicts the screening of five fungal isolates from garri processing environment. Three out of the five fungal isolates (A, B and C) showed zone of inhibition which indicates amylase production while the remaining isolates (D and E) showed no sign of amylase production. The statistical analysis carried out demonstrates that the mean zone of clearance for the three isolates were significantly different $(\mathrm{p}<0.05)$. Isolate $\mathrm{B}$ displayed the highest zone of clearance $(52 \pm 0.28)$ among the three fungal isolates, followed by Isolate A $(32 \pm 0.29 \mathrm{~mm})$. The isolate with the lowest zone of hydrolysis was Isolate C $(20 \pm 0.30 \mathrm{~mm})$. Isolate B which had the highest zone of hydrolysis of starch was therefore selected for further studies. The image of the hydrolysis zone of the fungal isolate is depicted in figure 1 .

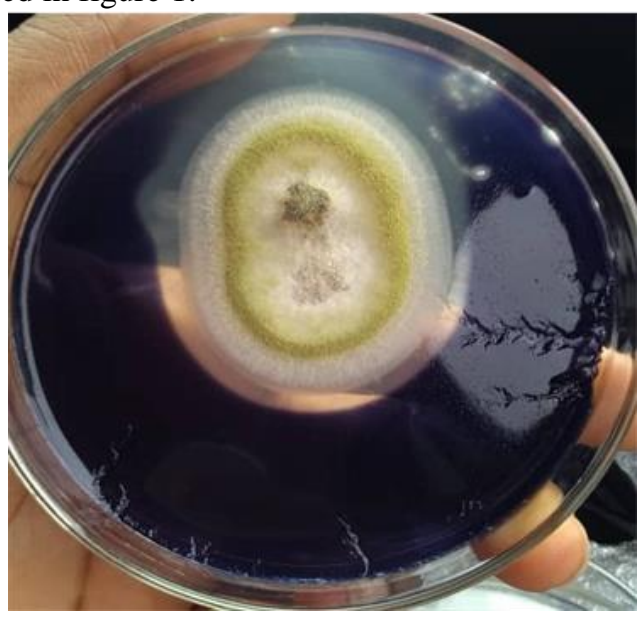

Figure 1. Image of the hydrolysis zone of the fungus

\section{B. Morphological properties of the selected fungus}

Macroscopically, the fungal isolate was greenish, velvety, cracked surface, yellow to orange transverse end on PDA plate. Microscopically, septate hyphae with conidia arranged like a mop-head. Using a reference standard, the fungal isolate was identified as Aspergillus flavus.

Table 1: Screening and selection of fungal isolates form amylase production

\begin{tabular}{|l|l|l|}
\hline S/No. & Isolates & Clear zone $(\mathrm{mm})$ \\
\hline 1 & A & $32.00 \pm 0.29^{\mathrm{a}}$ \\
\hline 2 & B & $52.00 \pm 0.28^{\mathrm{b}}$ \\
\hline 3 & C & $20.00 \pm 0.30^{\mathrm{c}}$ \\
\hline 4 & D & 0.00 \\
\hline 5 & E & 0.00 \\
\hline
\end{tabular}

Values show the means of triplicate analysis \pm SD. Values with different superscript $(a, b, c)$ down the column are significantly different at $95 \%$ confidence level.

\section{Molecular identification of the best amylase producing fungus}

The result of the agarose gel electrophoresis of the 18S rRNA genes of the fungus is depicted in Figure 2 while Figure 3 shows 
the amplicons obtained from PCR of fungus using ITS1 and ITS4. The result obtained showed that the fungal isolate falls within $1200 \mathrm{bp}$ and $1000 \mathrm{bp}$ with a DNA sequence of 551 base pair length. In Figure 4 showed the sequence of the fungal isolate RCBBR_AEAFUN2 while in Figure 5 according to phylogenetic analysis, the 18S rRNA sequence of the isolate RCBBR_AEAFUN2 was within the genus Aspergillus. This isolate RCBBR_AEAFUN2 had a 99\% similarity to other species but more closely $100 \%$ related to Aspergillus flavus (MF42408.1) than other species of Aspergillus and fungi.

\section{Growth profile of the fungus during time course study for amylase production}

The growth pattern of Aspergillus flavus (MF42408.1) during the time course study of amylase production is depicted in Figure 6. Maximum growth (2.35 g) of the fungus was observed after $48 \mathrm{~h}$ of incubation and declined steadily with further increase in fermentation time. ANOVA conducted revealed that there is significant $(\mathrm{P} \leq 0.05)$ variation in growth of the fungus with respect to fermentation time. The corresponding growth when optimum amylase production occurred was $0.82 \mathrm{~g}$ after $96 \mathrm{~h}$ of fermentation.

\section{E. $p H$ profile of the medium during time course study for amylase production}

Shown in Figure. 6 is the $\mathrm{pH}$ profile obtained during the time course study for the amylase production by the fungus. The result indicates that the initial $\mathrm{pH}$ of the medium decreased steadily from $\mathrm{pH} 6.9$ (day 0$)$ to $\mathrm{pH} 3.2\left(4^{\text {th }}\right.$ day i.e $120 \mathrm{~h}$ ) with increase in fermentation time. The $\mathrm{pH}$ at which optimum amylase was produced corresponds with $\mathrm{pH} 3.5$ (96 h).

\section{Protein content profile during time course study for amylase production}

The profile of protein secretion during the time course study for the enzyme production is presented in Figure 6. The result revealed that protein elaboration started almost immediately fermentation process commenced, reaching a peak (1.004 $\mathrm{mg} / \mathrm{ml}$ ) at $48 \mathrm{~h}$ of incubation. Protein secretion by the fungus decreased thereafter with increase in fermentation time. The highest amylase production was obtained when the protein content was $0.385 \mathrm{mg} / \mathrm{ml}$ after $96 \mathrm{~h}$ of incubation. The lowest was encountered at $24 \mathrm{~h}$ during the fermentation process.

\section{E. Time course study for amylase production by A. flavus RCBBR AEAFUN2}

The time course study for the amylase production by A. flavus RCBBR AEAFUN2 is presented in figure 6. It was observed that amylase secretion commenced after $24 \mathrm{~h}$ of fermentation with steady increase in its production with increase in incubation time. The highest enzyme production (2.18 $\mathrm{U} / \mathrm{ml} / \mathrm{min}$ ) was recorded after $96 \mathrm{~h}$ of incubation. However, beyond this period $(96 \mathrm{~h})$, amylase production declined as depicted in Figure 6. Optimum amylase production was achieved at $\mathrm{pH} 3$ with protein content of $1.004 \mathrm{mg} / \mathrm{ml}$ after 96 $\mathrm{h}$ of fermentation.

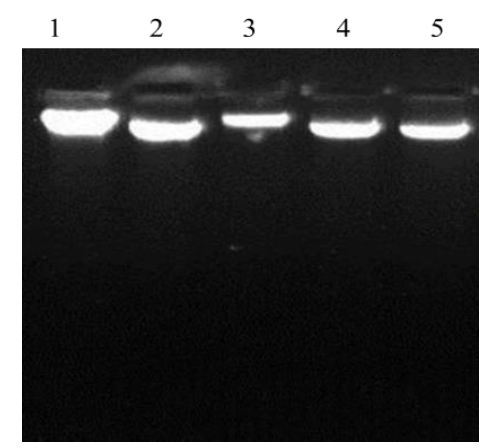

Figure 2. Agarose gel electrophoresis showing the amplified ITS of the fungal isolates. (No. 2 represent hyper producer amylase fungal isolate)

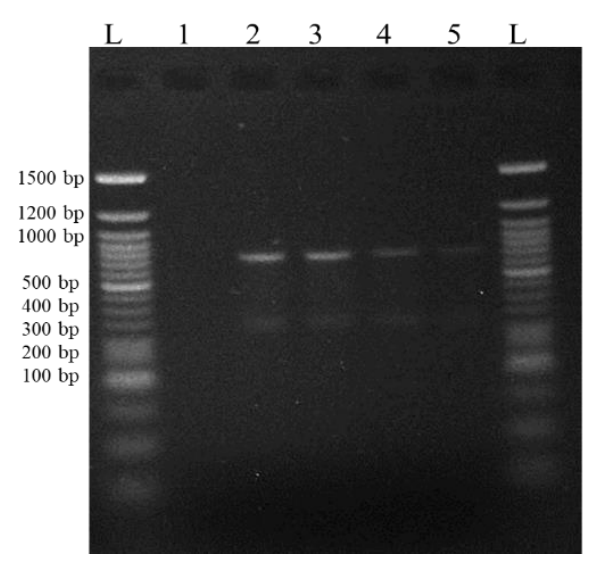

Figure 3. Amplicons obtained from PCR of fungal isolates using ITS1 and ITS4. L-100bp DNA Ladder. The No. 2 represent hyper producer amylase fungal isolate falls between $1000 \mathrm{bp}$ and $500 \mathrm{bp}$ with a DNA sequence of 551 base pair length.

TCTACCGAGTGTATGGTTGTAGCTTGGCGTTCTGCTAGCG CCGGCCGGGCCTACAGAGCGGGTGACAAAGCCCCATACG CTCGAGGATCGGACGCGGTGCCGCCGCTGCCTTTGGGGCC CGTCCCCCCCGGAGAGGGGACGACGACCCAACACACAAG CCGTGCTTGATGGGCAGCAATGACGCTCGGACAGGCATG CCCCCCGGAATACCAGGGGGCGCAATGTGCGTTCAAAGA CTCGATGATTCACGGAATTCTGCAATTCACACTAGTTATC GCATTTCGCTGCGTTCTTCATCGATGCCGGAACCAAGAGA TCCATTGTTGAAAGTTTTAACTGATTGCGATACAATCAAC TCAGACTTCACTAGATCAGACAGAGTTCGTGGTGTCTCCG GCGGGCGCGGGCCCGGGGCTGAGAGCCCCCGGCGGCCAT GAATGGCGGGCCCGCCGAAGCAACTAAGGTACAGTAAAC ACGGGGTGGGAAGGTTGGGGCTCGCTAGGAACCCTACAC TCGGTAATGATCCTTCGGCAGGTTCACCTACGGAAACC

Figure 4: Sequence of the hyper producer amylase fungal isolate No.2. 


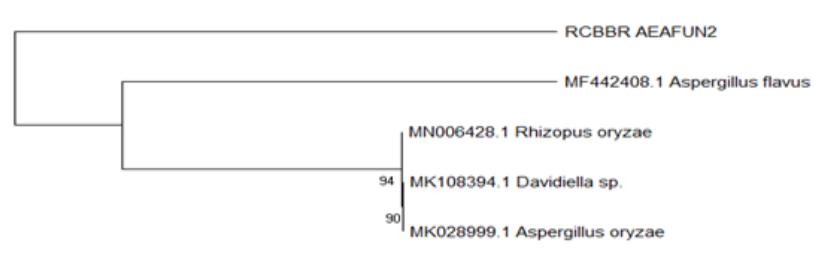

Figure 5. Phylogenetic tree reflecting the evolutionary distance between the fungal isolates

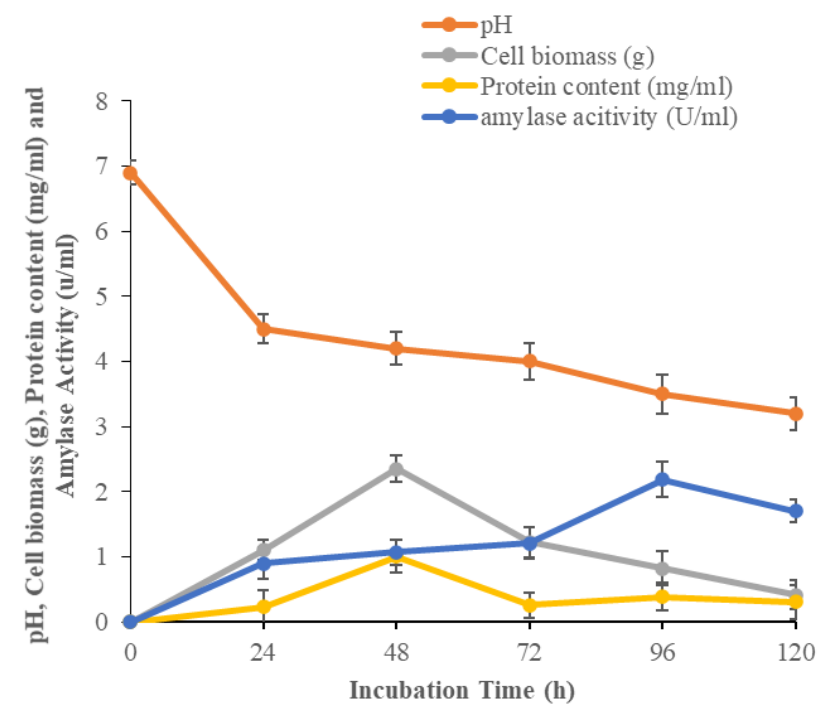

Figure 6. Time course studies for amylase production by Aspergillus flavus RCBBR AEAFUN2

\section{DISCUSSION}

In the present study, fungal-producing amylase was encountered in most of the fungal genera isolated from soil and waste water samples obtained from garri processing sites. This agrees with earlier studies carried out by Ogbonna et al. (2014). During screening of amylase-producing fungal isolates in this study, the highest zone of clearance $(52 \mathrm{~mm})$ was obtained which is an indication of the more efficient amylase-producing fungal isolate. Gautam et al. (2013) reported that the clear zone obtained when Aspergillus flavus (AFla-1) and A. flavus (AFla2) were screened for amylase production were $84 \mathrm{~mm}$ and 82 $\mathrm{mm}$, respectively on the average. This finding differed with the result obtained in this study. According to Gautam et al. (2013), zonation of fungal isolates subjected to starch hydrolysis does not show quantitative correlation with the amount of $\alpha$-amylase produced. Therefore, biochemical procedures are required to identify fungal strains with better amylolytic capabilities.

Our result indicated that the molecular characterization of the hyper producer amylase fungal isolate No.2 showed a $100 \%$ similarity to Aspergillus flavus after 18S rRNA of the isolate was sequenced and it is named as RCBBR AEAFUN2. The RCBBR AEAFUN2 is reported as a novel strain in Southern Nigeria as shown in Figure. 5. Bakri et al. (2009), Geetha et al., (2011), Fadahunsi and Garuba (2012) in their separate studies reported that Aspergillus flavus was the best producer of amylase among the fungal isolates screened for production of the enzyme. A recent study carried out by Elijah and Asamudo (2016) reported the presence of Aspergillus flavus among the fungal species isolated from cassava peel (CP) in a dumpsite using molecular characterization methods. Among the Aspergillus sp. identified, A. flavus had the lowest percentage relative abundance $(4.3 \%)$. The role of A. flavus in cassava peels is to reduce the levels of cyanogenic glycosides as well as nutritional improvement of the cassava peels by meaningfully enhancing its protein content. As indicated in the result, the cell biomass during the time course study increased with the incubation time until optimum biomass yield (2.35g) was obtained at $48 \mathrm{~h}$. Maximum growth of the fungus was observed at $\mathrm{pH}$ 4.5. Other researchers have reported similar results (Sunitha et al., 2012).

The medium used for amylase production monitored in relation to the incubation time $(24-120 \mathrm{~h})$ reflected a continuous decrease in $\mathrm{pH}$ from 6.9 to 3.2 . It was also observed that with decrease in fermentation medium $\mathrm{pH}$ elicited increase in amylase production by the fungus. The findings of this study indicated that maximum amylase production was achieved at $\mathrm{pH} 3.5$ and further decrease in $\mathrm{pH}$ resulted to decrease in amylase secretion. ANOVA carried out revealed that there was significant difference $(\mathrm{P} \leq 0.05)$ in enzyme productivity along variations in the $\mathrm{pH}$ of fermentation medium. According to Gautam et al. (2013), pH ranging from 3 - 7 is suitable for the growth of most common fungi. However, below $\mathrm{pH} 2$, some fungi could also grow. However, the amylase produced by fungi could considerably be denatured when exposed to low and high $\mathrm{pH}$ (Ibraheem et al., 2017). Our findings with rest to $\mathrm{pH}$ is in contrast with the observation of Gupta et al., (2008) who reported $\mathrm{pH} 5$ for optimum production of amylase by A. niger. A study carried out by Bakari et al. (2009) which reported Aspergillus flavus as the best producing extracellular amylase among 136 fungal isolates screened for enzyme production revealed that dry weight, protein and amylase produced by the isolate was $7.22 \mathrm{mg} / \mathrm{ml}, 1059.08 \mu \mathrm{g} / \mathrm{ml}$ and $11.13 \mathrm{IU} / \mathrm{ml}$, respectively. Only the result for protein content agrees with our report.

The data obtained on the time course study indicated that as the incubation time increase amylase production also increased and maximum amylase production was achieved at $96 \mathrm{~h}$ of incubation. Beyond this period relative production of the enzyme was decreased. Analysis of variance indicated that there is significant $(\mathrm{P} \leq 0.05)$ variations in amylase production along with fermentation period. Similar result was reported by 
Geetha et al. (2011) who observed that $13.03 \mathrm{U} / \mathrm{mg}$ was the highest quantity of amylase produced by Aspergillus flavus at $96 \mathrm{~h}$ incubation period. This result is interesting because it is most likely to reduce cost of producing the enzyme unlike optimum incubation period of 6 days reported by Fadahunsi and Garuba (2012) in a related study which involved A. flavus isolated from some indigenous foods undergoing biodeterioration. A shorter incubation period (3 days) for maximum yield $(0.281 \mathrm{U} / \mathrm{ml})$ of $\alpha$-amylase by Aspergillus niger was reported by Asrat and Girma (2018). According to their report, the quantity of amylase produced by A. niger steadily decreased on the $4^{\text {th }}, 5^{\text {th }}$, and $6^{\text {th }}$ day of incubation. However, a similar trend was encountered on the $5^{\text {th }}$ day of incubation based on our results. This could be attributed to release of glucose into the medium which result in catabolite repression as well as denaturation of proteins by proteolytic proteins secreted. According to Asrat and Girma (2018), a decrease in enzyme activity as incubation time increased could be as a result of required nutrient and moisture was available in the substrate which encouraged the growth of the fungal isolate. The result of this study also differed with the findings of Gupta et al., (2008) who reported an incubation period of 5 days for optimum amylase production by $A$. niger. The maximum amylase production which occurred after $96 \mathrm{~h}$ (4 days) is also not in agreement with the findings of Ire et al. (2017) who reported that amylase production by A. niger DTO:H15 occurred after $48 \mathrm{~h}$ of incubation at $\mathrm{pH}$ at initial $\mathrm{pH} 6.0$ under solid state fermentation. Our result also in contrast with the findings of Negussie et al., (2019) who reported that maximum amylase production by Penicillium sp was obtained at $72 \mathrm{~h}$ of incubation. According to Shafique et al., (2009), time course study for the production of amylase is governed by the properties of the culture as well as the growth rate and enzyme secretion. Enzyme elaboration usually occurs optimally during the late exponential and early stationary phases. However, an extension of fermentation time beyond this period, ultimately results to decrease in enzyme yield. Many works have associated depletion in nutrients, denaturation of enzymes, accumulation of toxic products as well as proteolysis are some of the causes of low secretion of the enzymes after early stationary phases (Lonsane et al., 1985; Negussie et al., 2019).

\section{V.CONCLUSION}

In this present study, five fungal strains were isolated from garri processing environment and screened both qualitatively and quantitatively for amylase production. Out of the five fungal strains encountered, only three showed potentials for amylase production. The most efficient amylase producer was identified as Aspergillus flavus (RCBBR_AEAFUN2) based on $18 \mathrm{~S}$ rRNA sequence and considered as a novel strain in southern Nigeria. The data obtained from the time course study revealed that the optimum amylase production $(2.18 \mathrm{U} / \mathrm{ml})$ by Aspergillus flavus (RCBBR_AEAFUN2) was achieved at $\mathrm{pH}$ 3.5 , corresponding to biomass concentration of $0.82 \mathrm{~g}$ after 96 $\mathrm{h}$ of incubation. The highest cell growth $(2.35 \mathrm{~g})$ and protein content $(1.0 \mathrm{~g} / \mathrm{ml})$ were recorded at $48 \mathrm{~h}$ of incubation, respectively. There is significant difference $(\mathrm{P} \leq 0.05)$ between amylase production by the fungus along fermentation period. The result of this study has proved that garri processing environment harbour amylolytic fungi which could be relevant bioprocessing industries and bioremediation processes. Further studies (which is currently ongoing) on the optimization of the process parameters for the amylase production and characterization will shed more light on the industrial potentials of this enzyme.

\section{CONFLICT OF INTEREST}

The authors declare no conflict of interest

\section{REFERENCES}

Aiyer, P.V. (2005). Amylases and their applications. African Journal of Biotechnology, 4(13), 1525-1529.

Asrat, B., Girma, A. (2018). Isolation, production and characterization of amylase enzyme using the isolate Aspergillus niger FAB-211. International Journal of Biotechnology and Molecular Biology Research, 9(2), 7-14.

Ayansina, A.D.V., Adebola, M.A., Adeyemi, A.O. (2014). Some microorganisms associated with soils exposed to cassava (Mannihot esculatum) peels. American Journal of Research Comm eunication, 2(9), 155-162.

Bakri, Y., Magali, M., Thonart, P. (2009). Isolation and identification of a new fungal strain for amylase biosynthesis. Polish Journal of Microbiology, 58(3), 269-273.

Batista, E., Watanabe, J.Y.M., Oliveira, V.M., Passarini, M.R.Z., (2018). Avaliaç ao da produç ao de amilase e protease por bacterias da Antartica. Revista Brasileira de Iniciaç ao Científica, 5, 13-29.

Cappuccino, J.G., Sherman, N. (2004). Microbiology a Laboratory Manual, (6th edition) Pearson Education, Pvt. Ltd, Delhi, India.

Dash, B.K, Rahman, M.M., Sarker, P.K. (2015). Molecular identification of a newly isolated Bacillus subtilis BI19 and optimization of production conditions for enhanced production of extracellular amylase. BioMed Research International, 9.

Elijah, A.I., Asamudo, N.U. (2016). Molecular characterization and potential of fungal species associated with cassava waste. British Biotechnology Journal, 10(4), 1-15.

Fadahunsi, I.F., Garuba, O.E. (2012). Amylase production by Aspergillus flavus associated with the bio-deterioration of starch-based fermented foods. New York Science Journal, 5(1), 13-18.

Fang, W, Xue, S., Deng, P., Zhang, X., Wang, X., Xiao, Y., Fang, Z. (2019). AmyZ1: a novel $\alpha$-amylase from marine bacterium Pontibacillus sp. ZY with high activity toward raw starches. Biotechnology for Biofuels, 12:95.

Felsenstein, J. (1985). Confidence limits on phylogenies: An approach using the Bootstrap. Society for the Study of Evolution, 39, 783-791.

Gautam, N., Singh, K.P., Modi, D.R. (2013). Screening of soil fungi for $\alpha-$ amylase activity. Journal of Recent Advances in Applied Sciences, 28, 110-112.

Geetha, K.N., Jeyaprakash, K., Nagaraja, Y.P. (2011). Isolation, screening of Aspergillus flavus and its production parameters for amylase under solid state fermentation. Journal of Applied and Natural Science, 3(2), 268273.

Gopinath, S.C.B., Anbu, P., Arshad, M.K.M, Lakshmipriya, T., Voon, C.H., Hashim, U., Chinni, S.V. (2017). Hindawi BioMed Research International, 9 Pages, https://doi.org/10.1155/2017/1272193.

Gupta, A., Gupta, V.K., Modi, D.R., Yadava, L.P. (2008). Production and characterization of $\alpha$-amylase from Aspergillus niger. Biotechnology, 7(3), 551-556. 
Ibraheem, L.J., Mezeal, I.A., Mizil, S.N. (2017). Manufacture enzyme from the fungus A. flavus. World Journal of Pharmaceutical Research, 6(10), 117125 .

Ire, F.S., Ike, V.C. (2014). Screening and Optimization of Process Parameters for the Production of Lipase in Submerged Fermentation by Aspergillus carbonarius (Bainer) IMI 366159. Annual Research \& Review in Biology, 4(16), 2587-2602

Ire, F.S., O.C. Eruteya, O.C., Amaechi, V. (2017). Optimization of culture conditions using One-Factor-at-Time Methodology and partial purification of amylase from Aspergillus niger of DTO: H5 under solid state fermentation. International Journal of Current Microbiology and Applied Sciences, 6(5): 307-325.

Ire, F.S., Nwanguma, A.C. (2020). Comparative Evaluation on Tannase Production by Lasiodiplodia plurivora ACN-10 under Submerged Fermentation (SmF) and Solid State Fermentation (SSF). Asian Journal of Biotechnology and Bioresource Technology, 6(1), 39-49,

Jukes, T.H., Cantor, C.R. (1969). Evolution of protein molecules. Mammalian protein metabolism, Academic press, New York, 3, 21-132.

Kolawole, O.P. (2014). Cassava processing and the environmental effect. World Sustainability Forum 2014-Conference Proceedings Paper. http://www.sciforum.net/conference/wsf-4

Lonsane, B.K., Ghildyal, N.P., Budiatman S, Ramakrishna, S.V. (1985) Engineering aspects of solid-state fermentation. Enzyme Microbial Technology,7(6), 258-265.

Lowry, O.H., Rosebrough, N.J., Farr, A.L., Randall, R.J., (1951). Protein measurement with the Folin-Phenol reagents. Journal of Biological Chemistry, 48, 17-25.

Miller, G.L. (1959). Use of dinitrosalicylic acid reagent for determination of reducing sugar. Analytical Chemistry, 31(3), 426-428.

Negussie F Bussa, Mesfin Moges, Manikandan Muthuswamy, Melese Abdisa (2019). Isolation and characterization of amylase enzyme from selected fungal strains of Washa Forest of North Shoa, Ethiopia. Science Journal of Biology \& Life Sciences. 1(2). SJBLS.MS.ID.000506.

Oboh, G. (2005). Isolation and characterization of amylase from fermented cassava (Manihot esculenta Crantz) waste-water. African Journal of Biotechnology, 4 (10), 1117-1123.

Obueh, H. O., Odesiri-Eruteyan, E. (2016). A study on the effects of cassava processing wastes on the soil environment of a local cassava mill. Journal of Pollution Effects and Control, 4(4), 1-4 doi:10.4176/23754397.1000177

Ogbonna, C. N., Okpokwu, N. M., Okafor, C. U., Onyia, C. E. (2014). Isolation and screening of amylase producing fungi obtained from garri processing site. International Journal of Biotechnology and Food Science, 2 (5), 8893.

Okolo, B.N., Ire, F.S, Ezeogu, L.I., Anyanwu, C.U., Odibo, F.J.C. (2000). Purification and some properties of a novel raw starch digesting amylase from Aspergillus carbonarius. Journal of the Science of Food and Agriculture, 81, 329 - 336.

Omilani, O., Abass, A.B., Okoruwa, V.O. (2019). Smallholder agroprocessors' willingness to pay for value-added solid waste management solutions. Sustainability, 11, 1759, doi:10.3390/su11061759

Ominyi, M.C., Ogbonna, J.C., Nwoba, E.G., Nwagwu K.E. Ukachi, R. (2013). Isolation and Screening of a-amylase and Glucoamylase Producing Fungi and their Application in Bioethanol Production. International Journal of Science and Nature, 4(1), 44-50.

Ottoni, J.R., de Silva, T.R., de Oliveira, V.M., Passarini, M.R.Z. (2020). Characterization of amylase produced by cold-adapted bacteria from Antarctic samples. Biocatalysis and Agricultural Biotechnology, 23 (2020) 101452, 1-8

Pham, J.V., Yilma, M.A., Feliz, A., Majid, M.T., Maffetone, N., Walker, J.R., Kim, E., Cho, H.J., Song, M.C., Park, S.R., Yoon, Y.J. (2019). A review of the microbial production of bioactive natural products and biologics. Frontiers in Microbiology, 2019, https://doi.org/10.3389/fmicb.2019.01404.

Pruitt, K.D., Tatusova, T., Maglott, D.R. (2005). NCBI Reference Sequence (Ref- Seq): A Curated Non-Redundant Sequence Database of Genomes, Transcripts and Proteins. Nucleic Acids Research, 33:501-504.

Saghai-Maroof, M.A., Soliman, K.M., Jorgensen, R.A., Allard, R.W. (1984). Ribosomal DNA spacer-length polymorphisms in barley: Mendelian inheritance chromosomal location and population dynamics. Proceedings of the National Academy of Sciences of the United States of America, 81, 8014-8018.

Saini, R., Saini, H.S., Dahiya, A. (2017). Amylases: characteristics and industrial applications. Journal of Pharmacognosy and Phytochemistry, 6(4), 1865-1871.

Saitou, N., Nei, M. (1987). The neighbor-joining method: A new method for reconstructing phylogenetic trees. Molecular biology and evolution, 4, 406-425.

Shafique, S., Bajwa, R., Shafique, S. (2009). Screening of Aspergillus niger and A. flavus strains for extracellular alpha-amylase activity. Pakistan Journal of Botany, 41(2): 897-905.

Singh, R., Mittal, A., Kumar, M., Mehta, P.K. (2016). Amylases: A note on current applications. International Research Journal of Biological Sciences, 5(11): 27-32

Sunitha, V.H., Ramesha, A., Savithas, C. (2012). Amylase production by endophytic fungi Cylindrocephalum sp. isolated from medicinal plant Alpinia calcarata (Haw.). ROSCOE. Brazilian Journal of Microbiology, 1213-1221.

Tamura, K., Dudley, J., Nei, M., Kumar, S. (2007). MEGA4: Molecular Evolutionary Genetics Analysis (MEGA) Mol. Bio. Evol., 24:1596-1599. 